\title{
Powrót terrorystki. Przypadek Brigitte Mohnhaupt
}

Beata Łazarz

TEKSTY DRUGIE 2016, NR 2, S. 363-375

DOI: $10.18318 /$ td.2016.2.19

Dowrót słynnych przestępców do społeczeństwa zawsze budzi silne emocje i obawy. Tak stało się również w przypadku Brigitte Mohnhaupt, jednej z przywódczyń tzw. drugiej generacji Frakcji Czerwonej Armii (Rote Armee Fraktion, RAF), gdy sąd w marcu 2007 roku, po spędzeniu przez nią 24 lat w więzieniu, podjął decyzję o zwolnieniu warunkowym. Wypuszczenie Brigitte Mohnhaupt na wolność wiązało się z nadaniem jej nowych danych osobowych i operacją plastyczną twarzy'. Przekonanie o ostatecznym zamknięciu historii terrorystki (w wyniku jej ujęcia i uwięzienia) osłabło, ustępując miejsca poczuciu możliwości powtórzenia, odrodzenia się zagrożenia, niejasnego i niedookreślonego.

Brigitte Mohnhaupt zasłynęła ze szczególnie brutalnych działań. Po raz pierwszy została aresztowana w czerwcu 1972 roku; skazano ją wtedy na cztery i pół roku więzienia. Ostatnie miesiące odbywania kary

1 Zob. np. K. Connolly Baader-Meinhof Terrorist to Be Freed after 24 years in Jail, "The Guardian" 13.02.2007; http://www.theguardian. com/world/2007/feb/13/germany.kateconnolly (13.08.2015).
Beata Łazarz - dr, w 2015 roku obroniła w Instytucie Sztuki PAN rozprawę doktorską Płeć przerażającego. Wizerunki terrorystekw sztukach plastycznych. Interesuje się sztuką współczesną, antropologią kultury wizualnej i psychoanalizą. 
spędziła w więzieniu Stammheim (Stuttgart), razem z przywódcami organizacji, Andreasem Baaderem i Gudrun Ensslin. Po wyjściu z więzienia w lutym 1977 roku stanęła na czele RAF. Miała udział, jako inspiratorka lub uczestniczka, w zamachu na Prokuratora Generalnego RFN Siegfrieda Bubacka (7.04.1977), zakończonej zabójstwem po nieudanej próbie porwania przewodniczącego zarządu Deutsche Banku Jürgena Ponto (30.07.1977) oraz porwaniu i zamordowaniu przewodniczącego Niemieckiego Związku Pracodawców Hannsa Martina Schleyera (5.09.1977)². W 1979 roku zorganizowała zamach na szefa NATO Aleksandra Haiga ${ }^{3}$ i na dowódcę 7 Armii w Heidelbergu w ramach sił NATO, generała armii amerykańskiej Fredericka Kroesena ${ }^{4}$; oba zamachy zakończyły się niepowodzeniem. Ostatecznie została aresztowana w 1982 roku i skazana na pięciokrotną karę dożywocia.

Trzydzieści lat po wydarzeniach Niemieckiej Jesieni ${ }^{5}$, na fali ponownego zainteresowania Frakcją Czerwonej Armii, wywołanej m.in. premierą filmu Baader-Meinhof ${ }^{6}$ oraz decyzjami sądu o warunkowym zwolnieniu kolejnych terrorystów z tego ugrupowania ${ }^{7}$, kwestię RAF podjęła mieszkająca w Holandii brytyjska artystka Esiri Erheriene-Essi ${ }^{8}$, tworząc w latach 2008-2011 serię prac Sympathy for the Devil'. The Wretched of the Earth [Współczucie dla diabła. Wyklęty lud ziemi]. Zadała ona przede wszystkim pytanie o to, jak należy dzisiaj - po zaprzestaniu przez organizację działalności i jej oficjalnym

2 K. Maniszewska Terroryzm a media. Środki masowego przekazu a rozwój terroryzmu w Republice Federalnej Niemiec w latach 1968-1998, Oficyna Wydawnicza ATUT, Wrocławskie Wydawnictwo Oświatowe, Wrocław 2006, s. 136.

3 Tamże, s. 142.

4 Tamże, s. 152.

5 Określenie ciągu przeprowadzanych przez terrorystów z RAF zamachów i porwań, którego kulminacja przypadła na wrzesień i październik 1977 roku.

6 Tyt. oryg. Der Baader Meinhof Komplex; reż. Uli Edel, prod. Niemcy, 2008 rok.

7 M.in. Christiana Klara i Birgit Hogefeld.

8 Ur. 18 sierpnia 1982 roku w Londynie, gdzie ukończyła studia; obecnie mieszka i pracuje w Amsterdamie; http://www.saatchiart.com/morrison55 (12.09.2015). Współpracuje z amsterdamską Galerią Ron Mandos; http://www.ronmandos.nl/artists/esiri-erheriene-essi\#qt-artist_ tabs-ui-tabs3 (12.09.2015).

9 Tytuł Sympathy for the Devil stanowi nawiązanie do piosenki zespołu The Rolling Stones z 1968 roku. 
samorozwiązaniu się ${ }^{10}$ - pamiętać ludzi, którzy w latach 70. XX wieku wzbudzali powszechne przerażenie.

Centralną postacią serii stała się właśnie przywódczyni drugiej generacji RAF. Pierwszymi pracami były przedstawienia twarzy protagonistki z okresu, kiedy była poszukiwaną terrorystką. Punkt wyjścia stanowiło powszechnie znane czarno-białe zdjęcie typu legitymacyjnego. Na obrazie Brigitte Mohnhaupt $^{\mathbf{1 1}}$ artystka oddała jej twarz w sposób wierny wyjściowej fotografii; zdecydowanymi pociągnięciami pędzla mocno zaakcentowała kanciaste rysy twarzy i głębokie cienie wokół zapadniętych oczu terrorystki. Jednak odmiennie niż na zdjęciu, na którym Mohnhaupt patrzy odbiorcom twardo w oczy - jej wzrok jest zwrócony nieco w bok, a spojrzenie jest puste. Zastosowanie odcieni sepii spowodowało przy tym, że przedstawienie kojarzy się ze starym zdjęciem: butna terrorystka stała się postacią, która przeszła do historii, a pamięć o niej powoli się zaciera.

Kolejne przedstawienia Brigitte Mohnhaupt, które powstały w 2009 roku, także były monochromatyczne: białe ${ }^{12}$, niebieskie ${ }^{13}$ i różowe ${ }^{14}$. Stopniowo zmieniała się ich wymowa. Przede wszystkim ze względu na odmienne zaakcentowanie oczu protagonistka sprawia wrażenie bardziej smutnej niż groźnej. Odczucie to zostaje pogłębione przez dodanie kilku plamek wyglądających jak krople wody na szkle, które sprawiają, że twarz terrorystki zdaje się oddzielona od spojrzenia widzów szybą. Wyobrażenie nabiera cech coraz bardziej oddalającego się melancholijnego wspomnienia o młodej kobiecie, która kiedyś złączyła swoje losy z organizacją terrorystyczną i poniosła klęskę, w wymiarze osobistym i historycznym.

Żółte, białe, różowe i niebieskie portrety Mohnhaupt zostały wykorzystane przez artystkę do stworzenia większej kompozycji: The Wretched of the

10 Nastąpiło to 20 kwietnia 1998 roku.

11 Link do obrazu: https://www.flickr.com/photos/basquiatrules/3030636184/ (15.07.2015).

12 Brigitte Mohnhaupt - White i Brigitte Mohnhaupt - White 2 (2009); linki do obrazów: https:// www.flickr.com/photos/basquiatrules/320182270o/ i https://www.flickr.com/photos/basquiatrules/320182086/ (15.07.2015).

Brigitte Mohnhaupt - Blue i Brigitte Mohnhaupt - Blue 2 (2009); linki do obrazów: https://www. flickr.com/photos/basquiatrules/3201822996/ i https://www.flickr.com/photos/basquiatrules/3200977439/ (15.07.2015).

14 Brigitte Mohnhaupt - Pink; link do obrazu: https://www.flickr.com/photos/basquiatrules/3201822854/ (15.07.2015). 
Earth [Wyklęty lud ziemi] ${ }^{15}$ (2009). Powtórzone przedstawienia terrorystki układają się w umieszczony centralnie krzyż. Wokół niego zostały rozmieszczone portrety przywódcy RAF Andreasa Baadera oraz kserokopie różnych dokumentów, być może odezw i ulotek, prezentujących stanowisko ideologiczne, z wieloma odręcznymi poprawkami i dopiskami, sprawiających przez to wrażenie dokumentów wciąż stanowiących przedmiot namysłu. Tytuł, w czytelny sposób nawiązując do tekstu Międzynarodówki ${ }^{\mathbf{1 6}}$, swego rodzaju nieformalnego ogólnoświatowego hymnu ruchów rewolucyjnych, odnosi się do lewackiej ideologii grupy, eksponowanej w licznych oświadczeniach, odezwach, manifestach, pisanych i publikowanych przez członków RAF także w czasie pobytu w więzieniu.

Wielokrotne powracanie do motywu wiążącego się ze zbiorową traumą kojarzy się z przebiegiem terapii. Zgodnie z teorią psychoanalityczną powtarzanie może prowadzić do oswojenia i zneutralizowania bolesnych doświadczeń. „W trakcie pracy nad rekonstrukcją wydarzeń traumatyczne wspomnienia ulegają transformacji i mogą zostać wbudowane w historię życia chorego"17; odnosi się to nie tylko do jednostek, ale i całych społeczeństw. Coraz bardziej melancholijne i odrealnione przedstawienia terrorystki zdają się dokumentować przebieg procesu przezwyciężania trudnych wspomnień. Jednak bezustanne powtarzanie może świadczyć o obsesyjnej fiksacji, w przypadku niemożności poradzenia sobie z traumą, i w efekcie nie prowadzić do zapanowania nad nią, a wręcz do jej pogłębienia, stania się „demonicznym natręctwem"18. Na ten trop naprowadzają zastosowane przez Esiri Erheriene-Essi przesunięcia, rozmazania, wyblaknięcia, kolorowanie, otwarcie nawiązujące do twórczości Andy'ego Warhola ${ }^{19}$. Wizerunek tej samej osoby, powtarzany w zbliżonych, ale za każdym razem nieco odmiennych wersjach, nabiera widmowej dynamiki, odnoszącej się zarówno do pamięci widzów, jak i do upartych prób powrotu wypartego. Przywołanie twarzy terrorystki,

15

16

17

Link do zdjęcia: https://www.flickr.com/photos/basquiatrules/3201821212/ (15.07.2015).

„Wyklęty powstań, ludu ziemi..."; tekst polski wg pochodzącego z początku XX wieku przekładu M. Markowskiej, działaczki Polskiej Partii Socjalistycznej.

7 J.L. Herman Przemoc, uraz psychiczny i powrót do równowagi, przeł. A. Kacmajor, M. Kacmajor, Gdańskie Wydawnictwo Psychologiczne, Gdańsk 2004, s. 185.

S. Freud Poza zasadą rozkoszy, w: tegoż, Psychologia nieświadomości, przeł. R. Reszke, Wydawnictwo KR, Warszawa 2009, s. 191.

W szczególności do opartej na fotografiach prasowych serii Death in America z początku lat 60. XX wieku. 
która już za życia stała się postacią przynależną do przeszłości, kojarzy się przy tym z figurą powracającej zmarłej ${ }^{20}$, postaci lokującej się w niejasnym polu między życiem a śmiercią, która nadal może stwarzać zagrożenie dla żywych.

Inny wymiar powrotu został poruszony w pracy Eloquence Doesn't Always Come with a Pretty Face... [Wymowa nie zawsze idzie w parze z ładną buzią...] $(2009)^{21}$. Tu nacisk został położony na ciągłość zjawisk, w tym przypadku trwałość form społecznego buntu. W obrazie wystylizowanym na klatkę kliszy fotograficznej przedstawione zostało zdjęcie z występu scenicznego Diany Ross z zespołem The Supremes ${ }^{22}$, sprawiające wrażenie naklejonego na ścianę pokrytą tapetą z niebieskimi portretami Brigitte Mohnhaupt. Zwielokrotniona postać terrorystki stanowi tło dla piosenkarek, fragmentarycznie przebijając się przy tym przez ich sylwetki, jakby zdjęcie było miejscami naderwane. Sama artystka tłumaczyła wymowę tej pracy w następujący sposób:

Cytat z Johna Baldessariego „niewyraźnie wymówione słowo historyczny brzmi jak histeryczny" najlepiej opisuje tematykę i cel moich prac. Wychodząc od tego, wciąż dążę do zniszczenia poczucia pewności i założeń znającego historię odbiorcy, w ten sposób zakłócając jego przekonanie o logicznym następstwie wydarzeń. Osiągam ten cel poprzez prowokowanie, przemieszczanie, zapożyczanie oraz, w niektórych przypadkach, grę z porządkiem zbiorowych i osobistych wątków historii, pamięci, mitów oraz kultury dawnej i obecnej. W moim alternatywnym świecie umieszczam grupę muzyczną z lat 6o. Diana Ross i The Supremes na tle powtarzającego się [portretu - przyp. B.Ł.] Brigitte Mohnhaupt, członkini grupy Baader-Meinhof/RAF, choć nie istnieje żaden dowód, by istniały między nimi jakiekolwiek związki. [...] Wiążę i umieszczam obok siebie znaczenia, sytuacje, wydarzenia i przedstawienia przeszłości, między którymi nie istnieje żaden inny związek poza faktem, że odnoszą się do tego samego czasu. Zatem w moim malarskim świecie członkowie RAF

„Wielu ludziom wydaje się w najwyższym stopniu niesamowite to, co wiąże się ze śmiercią, ze zwłokami lub z powracaniem zmarłych, z duchami i upiorami"; S. Freud Niesamowite, w: tegoż, Pisma psychologiczne, przeł. R. Reszke, Wydawnictwo KR, Warszawa 1997, s. 253. Link do zdjęcia: https://www.flickr.com/photos/basquiatrules/3212728866/ [15.07.2015]. 
inspirowali się muzyką zespołu The Supremes, a inspiracją dla przeboju grupy You keep me hangin' on były zbrodnie RAF. ${ }^{23}$

W twórczości Esiri Erheriene-Essi grupa The Supremes symbolizuje lata 6o., czas zamieszek rasowych, działalności Czarnych Panter ${ }^{24}$ i pastora Martina Luthera Kinga. Odwołania do zespołu Diany Ross służą oddaniu ciągłości kobiecego zaangażowania w walkę o cele społeczne i polityczne. Linia następstwa obejmuje Czarne Pantery i współpracującą z nimi Angelę Davis $^{25}$, przez terrorystki z RAF po członkinie rosyjskiej grupy Pussy Riot. W wyniku zastosowania zasady swobodnych skojarzeń możliwe i zasadne staje się wykorzystanie hasła Don't support the greedy, zaczerpniętego z jednego z plakatów The Supremes, w pracy For Assata z 2013 roku, poświęconej Pussy Riot.

Dzięki przywołaniu rozmaitych postaci kobiecego buntu - nie tylko pochodzących z różnych okresów i różnych państw, ale też różnie ocenianych - ujawnia się ambiwalencja odzwierciedlająca się w społecznym stosunku do terrorystek. Wynika ona z ambiwalencji wpisanej w samą sytuację buntu: może być on zarówno kreatywny (figura „prometejskiego buntownika”), jak i destrukcyjny. Może mieć na celu atak na społeczne hamulce, stanowiące niezbędną tamę dla agresji; z drugiej jednak strony może także stanowić wyraz sprzeciwu wobec ograniczania wolności oraz zmierzać do wyeliminowania zjawisk, które pętają rozwój i jednostki, i całej kultury. Jak ujął to Zygmunt Freud:

to, co w społeczeństwie ludzkim jest dążeniem do wolności, może być buntem przeciw istniejącej niesprawiedliwości, a tym samym sprzyjać dalszemu rozwojowi kultury i pozostawać w zgodzie z tą kulturą. Jednak dążenie to może również wywodzić się z tych warstw psychicznych, które

23 Zob. http://www.ronmandos.nl/artists/esiri-erheriene-essi\#quicktabs-artist_tabs=1 (15.07.2015); tłum. własne.

24 Partia Czarnych Panter (ang. Black Panther Party lub Black Panther Party for Self-Defense) - aktywna w latach 60. i 70. XX wieku radykalna amerykańska organizacja polityczna utworzona w celu ochrony czarnej mniejszości w USA i walcząca o jej prawa.

Angela Yvonne Davis (ur. 26 stycznia 1944 roku w Birmingham) - amerykańska komunistka i feministka, była działaczka na rzecz emancypacji Afroamerykanów w USA, profesor uniwersytecka (Uniwersytet Kalifornijski), związana m.in. z ruchem Czarnych Panter oraz ruchami na rzecz przeciwdziałania przemocy wobec kobiet i walki o prawa obywatelskie; https://pl.wikipedia.org/wiki/Angela_Davis (13.08.2015). 
pozostały po pierwszej i nieposkromionej formie osobowości, i w ten sposób stanowić podstawę wrogości wobec kultury. ${ }^{\mathbf{2 6}}$

Człowiek zbuntowany zatem to ten, który przekracza i neguje normy, zakłócając „naturalny” porządek świata, i przez to może być postrzegany jako bohater lub zbrodniarz, innowator lub jednostka zdegenerowana, wizjoner lub nihilista. Dążenie do wolności i sprawiedliwości może przybrać formę ślepego niszczenia, mordowania niewinnych ludzi, a także - w przypadku desperackiej walki o słuszną sprawę - bezprzykładnej odwagi i szlachetnego poświęcenia. Metodami stosowanymi przez terrorystów posługiwali się i posługują m.in. partyzanci, powstańcy, bojownicy o wolność, działacze niepodległościowi czy rewolucjoniści.

Wykorzystaniu postaci Mohnhaupt jako ikony kobiecego buntu w wymiarze ponadnarodowym i ponadhistorycznym sprzyjał międzynarodowy i niemal mesjański wymiar działalności RAF. O tym, że terroryści z tego ugrupowania postrzegali siebie jako część szerszego ruchu, świadczy już sama jego nazwa: „frakcja” to fragment większej całości. W swoich licznych wystąpieniach propagandowych akcentowali ogólnoświatowy sens prowadzonej walki, odwołując się m.in. do sytuacji w Wietnamie, Palestynie czy na Kubie. I tak np. zamachy na obiekty armii amerykańskiej w RFN (maj 1972 roku) miały być „odpowiedzią na bombardowania Wietnamu"27. W wydanym w 1984 roku tekście Wyjaśnienie odnośnie roku 1977, napisanym wspólnie z Christianem Klarem, Brigitte Mohnhaupt przedstawiała działalność RAF m.in. jako reakcję na dojście do władzy sandinistów w Nikaragui i komunistów w Kambodży; porównywała także działalność Frakcji Czerwonej Armii do akcji przeprowadzanych przez Czerwone Brygady we Włoszech, IRA w Irlandii oraz ETA w Hiszpanii. „RAF jest według niej częścią ruchu wyzwoleńczego, który w ostatnich piętnastu latach rozwinął się w Europie i który stanowi integralną część ruchów wolnościowych na innych kontynentach"28. Poczucie internacjonalistycznej solidarności znajdowało wyraz nie tylko w wystąpieniach w imieniu narodów poddanych opresji ze strony kapitalistycznych potęg, lecz także w podziwie dla działalności innych ugrupowań,

Z. Freud Kultura jakoźródło cierpień, przeł. J. Prokopiuk, Wydawnictwo KR, Warszawa 1992, s. 84. 
jak np. włoskie Czerwone Brygady czy też wspomniane już Czarne Pantery. Astrid Proll deklarowała wprost: „byliśmy fanami Czarnych Panter"29.

W kolejnych pracach: She i She 2 [Ona i Ona 2] (2011 ${ }^{30}$;) oraz Masquerade [Maskarada] ${ }^{31}$ (2012) Esiri Erheriene-Essi położyła nacisk na przemiany twarzy terrorystki. She i She 2 to przedstawienia Brigitte Mohnhaupt mające za podstawę policyjne zdjęcie z 2007 roku, sprzed wypuszczenia jej z więzienia, kiedy miała już 58 lat. Tytuł, zgodnie z deklaracją artystki, stanowi odwołanie do piosenki She amerykańskiego punkrockowego zespołu Misfits z 1977 roku, opowiadającej o dziewczynie z dobrego domu, która weszła na ścieżkę przemocy i ucieka przed wymiarem sprawiedliwości. Ze słów piosenki nie poznajemy jej motywacji. Jawi się jako postać tajemnicza i zarazem ambiwalentna: „Jest dobra i jest zła/nikt nie rozumie”. Ona to również postać bez imienia i nazwiska; wiąże się to zapewne z zamazaniem tych podstawowych danych samej Brigitte Mohnhaupt.

W pierwszej wersji rysy terrorystki zostały w dużym stopniu zmienione i zatarte; krawędź obrazu odcięła lewą część twarzy i podbródek, twarz została spłaszczona. Uwagę przyciągają mocno wyeksponowane oczy: na tym przedstawieniu protagonistka patrzy jakby z zadumą wprost na widzów, a cień poniżej lewego oka sprawia wrażenie spływającej łzy lub krzyża. W drugiej wersji została pokazana tylko środkowa część twarzy, z zamazanymi rysami; silnie podkreślone zostały tylko oczy i usta. Oczy, skierowane gdzieś w górę, mają smutny wyraz, dodatkowo podkreślony przez plamki kojarzące się ze łzami (jedna z nich częściowo przesłania tęczówkę lewego oka) oraz wygięcie w dół kącików ust. Tonąca w cieniu prawa część twarzy wygląda jak pokryta ranami. Można to odczytać jako sugestię głębokiej przemiany, nie tylko związanej z upływem lat i pobytem w więzieniu, lecz także ze zmianą osobowości, być może żalem za popełnione czyny. Nie jest ona jednak pewna i, co więcej, nie ma możliwości jej potwierdzenia lub wykluczenia. W wymiarze wizualnym wątpliwości akcentuje sposób wykorzystania zbliżenia twarzy, by w istocie doprowadzić do jej zamazania: jak pokazał już Michelangelo Antonioni $^{32}$, przeglądanie zdjęć kadr po kadrze, wpatrywanie się w kolejne

29 W. Gadowski, P. Wojciechowski Tragarze śmierci, s. 313. Linki do obrazów: https://www.flickr.com/photos/basquiatrules/5373596087/ i https://www. flickr.com/photos/basquiatrules/5373596561/ (15.07.2015). Link do obrazu: https://www.flickr.com/photos/basquiatrules/7005805274/ (15.07.2015). 
szczegóły, powiększanie ich, może paradoksalnie prowadzić do zatarcia obrazu i w efekcie do powstania jeszcze większej niepewności...

Odrealnienie twarzy osiągnęło apogeum w pracy Masquerade. Mohnhaupt wygląda na nim znowu jak młoda kobieta, ale niepodobna do postaci znanej nam ze zdjęć z lat jej młodości - jest to jakby retrospektywnie odmłodzona twarz terrorystki, wychodzącej po latach na wolność. Szeroko otwarte oczy, patrzące gdzieś w górę, i wyraźnie zaznaczone pełne usta nadają jej wyraz wrażliwości i łagodności. Stworzenie fikcyjnego wizerunku młodej kobiety, różniącej się od ikonicznego przedstawienia terrorystki, zdaje się wyrażać dążenie do zmniejszania rozziewu między tym, co było, a tym, co jest. Specyficzne, retroaktywne naśladowanie pracy czasu wiąże się z niemal ostentacyjnym przekształcaniem teraźniejszości i przeszłości w obraz mentalny, scalaniu ich w sensowną całość z punktu widzenia chwili obecnej, a nie historii. Celem tego obrazu - choć jego punktem wyjścia była fotografia - nie jest mimetyczne odzwierciedlenie rzeczywistości, lecz artystyczna transpozycja odległego oryginału, dokonana w taki sposób, by zapanować nad wspomnieniami, choć zarazem już sam tytuł sugeruje możliwość, że mamy do czynienia z maskaradą (lub nakładaniem przemocą maski). Zaakceptowanie nowego oblicza jako „tej właściwej” twarzy Mohnhaupt pozwala na dostrzeżenie, że bezwzględna terrorystka i kobieta wypuszczona po latach na wolność, zmieniona pod względem fizycznym, a zapewne i psychicznym, to jedna i ta sama osoba. Dzięki temu możliwa staje się konfrontacja $\mathrm{z}$ ambiwalencją: jednoczesnym występowaniem przeciwstawnych odczuć w stosunku do tego samego obiektu, rezygnacja z postrzegania go w kategoriach czarno-białych i otwarcie się na możliwość zmiany, zarówno samej terrorystki (zmiany, która nie musi sprowadzać się do maskarady), jak i emocji odbiorców w stosunku do niej.

Esiri Erheriene-Essi w autorskich komentarzach do serii Sympathy for the Devil. The Wretched of the Earth odwołuje się do koncepcji archeologii wiedzy Michela Foucaulta, w szczególności akcentując rolę pęknięć, szczelin, przesunięć i transformacji. Archeologia

bada stopień i formę przenikalności dyskursu: podaje zasadę jego nakładania się na łańcuch kolejnych zdarzeń, określa operatory, za pośrednictwem których zdarzenia przekładają się na wypowiedzi. ${ }^{33}$ 
Artystkę interesowały zatem

konflikty między starym a nowym, opór, jaki stawia wiedza nabyta, represyjny nacisk, jaki wywiera ona na rzeczy nigdy jeszcze nie powiedziane, zasłony, którymi je maskuje, oraz zapomnienie, na które udaje się jej niekiedy je skazać; ale [...] też ułatwienia, które po cichu i z daleka przygotowują przyszłe dyskursy. ${ }^{34}$

Na trop możliwości odczytania tych prac przez pryzmat psychoanalizy naprowadzają jednak uwagi, w których artystka zarówno dzieli się własnymi przeżyciami i trudnościami związanymi z koniecznością zmierzenia się z tematem terroryzmu, jak i odnosi się do emocji doświadczanych na poziomie społecznym. Dodane pod zamieszczonymi w Internecie reprodukcjami wyjaśnienie, że podstawą aktu twórczego było powtórzenie i nieugięte patrzenie w twarz ludzi, których czyny były nieludzkie, wskazuje, że seria stanowi świadectwo dążenia autorki do przezwyciężenia lęku. Wymagało to zmagania się z własnymi emocjami, znajdującego odzwierciedlenie w jej dopiskach, jak np. w podkreślaniu wymogu „patrzenia bez lęku” lub w wezwaniu „Boże, daj mi siłę".

Artystka przyjęła na siebie w pewnym sensie rolę psychoanalityka, dokonując analizy swoich odczuć i jednocześnie podejmując rozmowę z podmiotem zbiorowej pamięci. W ujęciu Freuda celem terapii jest pojednanie z wypartymi treściami psychicznymi.

Chory musi się zdobyć na odwagę, musi zwrócić uwagę na swe objawy chorobowe. Sama choroba nie może mu się wydawać czymś, co można by zlekceważyć - pacjent musi ją raczej traktować niczym godnego siebie przeciwnika, niczym część swej istoty, niczym coś, co ugruntowuje swe istnienie na dobrych motywach, coś, z czego powinien zaczerpnąć coś wartościowego dla swego późniejszego życia. ${ }^{35}$

Przezwyciężenie traumy, za sprawą odnalezienia nowego kształtu i sensu przeszłych wydarzeń, pozwala ukształtować pamięć na nowo.

34 Tamże, s. 166.

35 S. Freud Przypominanie, powtarzanie, przepracowywanie, w: tegoż, Technika terapii, przeł.

R. Reszke, Wydawnictwo KR, Warszawa 2007, s. 171. 
W tym przypadku była to autoterapia, prowadzona niejako w imieniu społeczeństwa. Autorka serii Sympathy for the Devil. The Wretched of the Earth dążyła do dania przykładu i przekazania swojego osobistego doświadczenia za pośrednictwem dzieł artystycznych. Zapis własnych przeżyć psychicznych miał służyć za środek dotarcia do emocji na poziomie społecznym, stać się próbą zmierzenia się z powrotem wypartego i zaproponowania na nowo ram pamięci, określenia, jak powinno się pamiętać terrorystów. W toku tej swoistej psychoterapii Esiri Erheriene-Essi starała się zachowywać „otwartość umysłu i zająć pozycję współczującego świadka, a nie psa gończego"36.

Punktem centralnym serii są twarz i tożsamość Brigitte Mohnhaupt, wokół których koncentruje się pamięć o jej terrorystycznej przeszłości a które ulegały głębokim przemianom. Co więcej, przemiany te są nam dostępne jedynie do pewnego stopnia; w istocie nie znamy ani jej nowego wizerunku, ani jej myśli, przeżyć i emocji. Celem nie było jednak ustalenie, , jak było naprawdę", lecz zmiana postawy twórcy i odbiorcy. Temu służyły zarówno wezwania do współczucia, jak i zastosowana symbolika, zwłaszcza kilkakrotnie powracający znak krzyża. Symbolizuje on zapewne przede wszystkim żałobę po ofiarach zamachów terrorystycznych. Być może jest to jednak także znak żałoby po młodej kobiecie, której już nie ma; po kobiecie, której życie zostało naznaczone terroryzmem; po kobiecie, której wybory życiowe doprowadziły do klęski moralnej i historycznej. Wypuszczenie terrorystki na wolność dało jej szansę na przeżycie ostatnich lat życia w odmienny, godny sposób; być może również na odkupienie grzechów. Wiadomo, że w czasie pobytu w więzieniu przez 15 lat Brigitte Mohnhaupt znajdowała się pod opieką duszpasterską pastora, który był przekonany o jej głębokiej przemianie moralnej37; zarazem jednak nigdy publicznie nie wyraziła skruchy ${ }^{38}$.

Warunkiem twórczości artystycznej - co podkreślała Hanna Segal - jest dokończenie pracy żałoby. Proces twórczy jest związany z pozycją depresyjną: artystyczna kreacja wymaga od twórcy zmierzenia się z lękiem, przezwyciężenia rozszczepienia typowego dla pozycji paranoidalno-schizoidalnej i pogodzenia się z ambiwalencją. Wtedy możliwe staje się wyrażenie treści, które są związane z traumatycznymi doświadczeniami, w postaci symbolicznej,

36 J.L. Herman Przemoc, uraz psychiczny i powrót do równowagi, s. 191.

37 Zob. np. K. Connolly Baader-Meinhofterrorist to be freed.

38 Zob. np. Terrorysta z RAF wyjdzie na wolność; http://www.wprost.pl/ar/145312/Terrorysta-z-RAF-wyjdzie-na-wolnosc (15.08.2015). 
a więc ekspresja artystyczna ${ }^{39}$. Wydarzenie lub zjawisko historyczne może zostać ponownie odegrane w nowej formie, pozwalającej na rozwiązanie konfliktów psychicznych z nim związanych.

Uwagi Esiri Erheriene-Essi wskazują na to, że tworzone przez nią wizerunki niemieckiej terrorystki stanowiły przede wszystkim taką próbę znaczącego odtworzenia obiektu ${ }^{40}$ przez powrót do traumatycznej przeszłości i próbę ponownego opowiedzenia jej ze zmienionej perspektywy. Przyjęta przez nią strategia twórcza nie opiera się na interioryzacji krzywdy, własnej lub cudzej, lecz na wezwaniu do ponownej konfrontacji ze źródłem przerażenia, by określić na nowo relację z terrorystką (taką, jaką była kiedyś i jaka jest obecnie) i stworzyć przestrzeń dialogu. Warunkiem jest uświadomienie sobie ambiwalencji i niejasności związanych z jej postacią, zmierzenie się z własnymi emocjami oraz obudzenie w sobie współczucia. Taka „terapia” nie musi zakończyć się sukcesem, ale stwarza możliwość przepracowania jednego z bolesnych doświadczeń historycznych.

39 H. Segal Teoria Melanie Klein w praktyce klinicznej oraz Psychoza i twórczość artystyczna i inne eseje, przeł. D. Golec, G. Rutkowska, A. Czownicka, Gdańskie Wydawnictwo Psychologiczne, Gdańsk 2006, s. 253.

40 Zob. G. Pollock Differencing the Canon. Feminist Desire and the Writing of Art's Histories, Routledge, London-New York 1999, S. 194-195. 


\section{Abstract}

\section{Beata Łazarz}

INSTITUTE OF ART OF THE POLISH ACADEMY OF SCIENCES

The Return of the Woman Terrorist: This Case of Brigitte Mohnhaupt

This article aims to analyse works from the series'Sympathy for the Devil?/The Wretched of the Earth' (2008-2011) by the British artist Esiri Erheriene-Essi. The central figure is Brigitte Mohnhaupt, the German terrorist responsible for the most brutal attacks perpetrated by the Red Army Faction (RAF). Łazarz draws on psychoanalytical tools, especially ones based on the works of on Sigmund Freud and Hanna Segal. Her analysis suggests that the creation of Mohnhaupt's portrait allowed the artist to engage in a sort of public autotherapy that made it possible to confront herself with her own emotions relating to terrorism, to become aware of ambivalence and to become empathic towards the protagonist. Her audience can participate in this experience, both consciously and unconsciously.

\section{Keywords}

terrorism, psychoanalysis, art 